\title{
OVERVIEW OF UNDERGROUND COAL GASIFICATION (UCG) - FOR A PROMISING FUTURE OF INDIA
}

\author{
Abhay Kumar \\ Department of Mechanical Engineering, \\ Jharkhand Rai University, Ranchi, \\ Jharkhand, INDIA
}

\begin{abstract}
Underground coal gasification (UCG) is a process to use and convert deep and economically un-mineable coal into syngas for further use in electric power, liquid fuels and synthetic natural gas etc. Underground Coal gasification is a very promising option for the future use of coal present in INDIA. This paper provides a summary of the UCG description and its selection criteria. The current status of this technology in various countries are also been discussed. Finally, the potential of UCG as a means for producing syngas from un-mineable deep sited coal has been discussed and its challenges as well as opportunities involved.
\end{abstract}

Keywords: Underground Coal Gasification, Clean coal technology; conversion, gasification; liquefaction.

\section{INTRODUCTION}

Coal and lignite reserves in INDIA constitutes to a total of more than 350 billion tons. The annual production of coal in 2015-16 was about 640 million tons, but recently Coal India Limited envisaged production of 1 billion tones by the end of the decade. At present Coal is responsible more meeting of more than 60 percent of energy needs of the country [1]. Coal being a major source of energy, contributing almost $60 \%$ of the energy needs of the world, coal is unlikely to become an acceptable replacement for uncertain supplies of oil and natural gas. The main energy source at present in India is coal and at the same time burning coal, pollutes the environment by generating $\mathrm{SOx}$, NOx and various pollutants dangerous for the human health. Under the above scenario we have to search a suitable replacement technology and methodology to address this environmental issue along with the energy requirement. Underground coal gasification seems to be one technology which can become the potential candidate to address the environmental issues at the same time give us the sustainable energy in the economic manner. It can also act as a promising option for the future use of coal.

\section{LITERATURE REVIEW}

Background \& Efforts made for UGC in India: India has very scarce experience of UCG. Although, many deeper coal seams and deeper lignite deposits not economically viable to mine by conventional mining techniques are available and are good prospects for UCG. Abandoned mines with shallow coal deposits with difficult geo-mining conditions also can be used for UCG to its advantage.

The study of reserves and availability of Indian coal have indicated that a major portion of the reserve consists of weakly to non-coking variety of bituminous, sub-bituminous and lignite coal which are distributed all over India, located at different depths. [2] The government of India has identified 8 coal blocks for the development of underground coal gasification. Such projects may strengthen India's efforts to fulfil its clean energy commitments. India has assured to scale back its emissions intensity of its gross domestic product by $33-35 \%$ by 2030 compared with 2005 levels [3]. Till now this technology hasn't progressed well in India, but it can progress if there are proper research to encounter certain challenges and government support including environmental challenges, such as groundwater contamination with this technology.

In India, UGC was engaged up in the 1980s by Oil and Natural Gas Corp. Ltd (ONCC) and Coal India Ltd (CIL), the country's two major public sector companies, with technical assistance from the thenUSSR. Government of India, within the year 1981 has signed a protocol for development of UCG with erstwhile Soviet Union. In 1984 the Government of India constituted a National Committee on UCG [4]. ONGC under the pilot project has drilled two pilot wells near Mehsana city, in North Gujarat. Coal Reserves of about 63 billion tones at a depths starting from $700-1700 \mathrm{~m}$. Carbon content (dry ash free basis) between $72-76 \%$, Methane content varying from $1-6 \mathrm{~m} 3 / \mathrm{t}$. Hydrogen content was high compared to other lignite deposits in India . 
Other activities that have taken place with respect to the underground coal gasification in India are as follows:

a) The Ministry of Coal, Government of India, has awarded an S\&T study project to the Neyveli Lignite Corporation.

b) ONGC has signed an Agreement for Collaboration with Skochinsky Institute of Mining, Russia in Nov. 2004.

c) MOU's has been signed between ONGC and NLC, GMDC, GIPCL, CIL and SCCL.

d) Vastan mine block of GIPCL has been identified suitable mine block of for UCG.

e) Five additional blocks are also being studied. Five blocks were found NOT suitable.

f) GAIL signed MoC with Ergo with Ergo Exergy, Canada and with Govt of Rajasthan. Land has been earmarked to of Rajasthan. Land has been earmarked to GAIL.

Current Status of Underground Coal Gasification Technology in India

The first ever pilot project of Underground Coal Gasification was carried out in Vastan mine block, [4] Surat, Gujarat in collaboration with Gujarat Industries Power Company Ltd. ONGC obtained the environmental clearance for the project from Ministry of Environment \& Forests (MoEF), GOI, after final meeting with Expert Appraisal Committee of MoEF which was held on January 15, 2010.

UCG is the only feasible technology which has the potential to convert coal resources to coal reserves. ONGC has now taken up Vastan Mine block site belonging to GIPCL in Naninaroli, Surat district, Gujarat as an R\&D Pilot Project to establish UCG technology in collaboration with $\mathrm{M} / \mathrm{s}$ National Mining Research Center-Skochinsky Institute of Mining (NMRC-SIM), Russia. Agreement of Collaboration (AOC) to co-operate in the Services, Operations, Development and Research related to Under Ground Coal Gasification (UCG) in India with ONGC has further been extended up to March 4, 2020. Mining lease with respect to the Vastan Pilot Project has already been awarded to GIPCL.

There is considerable interest in the implementation of 8 Central Mine Planning and Design Institute (CMPDI) in consultation with organizations like Neyveli Lignite Corporation Limited (NLC), Geological Survey of India (GSI), Director General of Mine Safety (DGMS), Singareni Collieries Company Limited (SCCL) has identified following 7 blocks (5 lignite \& 2 coal) for development of Underground Coal Gasification (UCG) technology in India. These Blocks are as follows:
A. Lignite Blocks

1. Sindhari West, Barmer,Rajasthan

2. Chokla North,Barmer,Rajasthan

3. Nimbalkot, Barmer,Rajasthan

4. Nagurda, Barmer,Rajasthan

5. Dungra, Surat,Gujarat

B. Coal Blocks

1. Yellendu (Dip Side)-SCCL

2. Bandha-Singrauli Main Basin

UCG program status worldwide[5]

\section{Sl. Country Status / Activities}

No.

1. United Lawrence Livermore National

States Of Laboratory recently conducted America two large projects in Washington and Wyoming and Cook Inlet Region Inc. (CIRI) has proposed an underground coal gasification (UCG) plant on CIRI lands on the west side of Cook Inlet, about 20 miles north of Tyonek near the Beluga-area natural gas fields. If approved, the 100 megawatt plant would be the first UCG project in the United States.

2. Canada Laurus Energy is currently preparing several $\varepsilon \mathrm{UCG}$ power projects in Alberta and Nova Scotia. The $\varepsilon$ UCG gas from coal deposits in the immediate vicinity of two coal-fired power plants in Nova Scotia, can be co-fired with imported coal and petcoke to significantly reduce $\mathrm{SO}_{\mathrm{x}}$ emissions and to provide large fuel cost savings for the plants. The total capacity fueled by $\varepsilon \mathrm{UCG}$ in the above projects is planned to exceed 1,000 MWe. Laurus is planning several other industrial $\varepsilon U C G$ plants in Canada to produce chemicals and liquid fuels.

3. Chile Carbon Energy, Australia and Antofagasta Minerals jointly working for developing UCG project in Mulpun.

4. Argentina Carbon Energy Signs Technology Licensing MOU for a Commercial Scale UCG Project in Argentina. Carbon Energy becomes the underground coal gasification technology partner of Delmo, an Australian diversified investment group, for a commercial scale UCG project in Argentina, South America. It is proposed that the commercial scale project will initially generate $300 \mathrm{MW}$ of electricity with further expansions planned. 


\begin{tabular}{|c|c|c|}
\hline Sl. & Country & Status / Activities \\
\hline 5. & $\begin{array}{l}\text { Uzbekista } \\
\mathrm{n}\end{array}$ & $\begin{array}{l}\text { Linc Energy and Yerostigaz joint } \\
\text { venture UCG operation generates } \\
\text { about } 1 \text { million cubic meters of } \\
\text { syngas per day in Angren and is } \\
\text { running since } 1960 \text {. }\end{array}$ \\
\hline 6. & $\begin{array}{l}\text { South } \\
\text { Africa }\end{array}$ & $\begin{array}{l}\text { Eskom ltd, Ergo Energy and } \\
\text { Sasol New Energy ltd. are } \\
\text { working together to generate } \\
\text { around } 1200 \mathrm{MWe} \text { of electricity. }\end{array}$ \\
\hline 7. & China & $\begin{array}{l}\text { Zhengzhou Coal Industry Group } \\
\text { Co Ltd and Carbon Energy, } \\
\text { Australia UCG project in Inner } \\
\text { Mongolia, China. }\end{array}$ \\
\hline 8. & India & $\begin{array}{l}\text { Abhijeet, India, AE Coal } \\
\text { Technologies Ltd making efforts } \\
\text { to obtain the block for conducting }\end{array}$ \\
\hline 9. & $\begin{array}{l}\text { Banglades } \\
\mathrm{h}\end{array}$ & $\begin{array}{l}\text { Abhijeet Group, Indian, Silicon } \\
\text { Tech, has proposed to develop } \\
\text { UCG facilities in the Jamalganj } \\
\text { coal mine in Joypurhat and } \\
\text { further plan to install a power } \\
\text { plant under a joint venture with } \\
\text { Petrobangla. }\end{array}$ \\
\hline
\end{tabular}

\section{Chemistry Involved In UGC}

The UCG process mainly takes place in three different zones: drying, pyrolysis, combustion and solid coal gasification. In the drying zone, the moist coal located underground is heated and becomes dry coal by removing the moisture from it. By further heating the coal, the pyrolysis reaction takes place, starting at temperatures around $350-400{ }^{\circ} \mathrm{C}$, which causes the coal to lose weight, creating volatile components and the solid material known as coal. pyrolyzed gases for the production of the product gas or commonly known as synthesis gas.

The principal oxidation reactions occurring during forward gasification are as indicated below:

$$
\begin{array}{ll}
\mathrm{C}+02 \text {---- } \mathrm{C} 22 & +394 \mathrm{KJ} / \mathrm{Mol} . \\
\mathrm{C}+1 / 2 \mathrm{O} 2 \text {----- } \mathrm{CO} & +111 \mathrm{KJ} / \mathrm{Mol} . \\
\mathrm{CO}+1 / 2 \mathrm{O} 2 \text {----- } \mathrm{CO} 2 & +283 \mathrm{KJ} / \mathrm{Mol} .
\end{array}
$$

These oxidation reactions consume the available oxygen over a zone thickness of $0.3 \mathrm{~m}$ or less. Reaction indicated above (2) yielding combustible gas is favoured at temperatures above $725^{\circ} \mathrm{C}$. The endothermic gasification reactions include the steam-char reaction and the carbon dioxide reduction reaction:

$$
\begin{aligned}
& \mathrm{C}+\mathrm{H} 20--\mathrm{CO}+\mathrm{H} 2 \quad-131 \mathrm{KJ} / \mathrm{Mol} \text {. } \\
& \mathrm{CO} 2+\mathrm{C}----2 \mathrm{CO} \quad-172 \mathrm{~kJ} / \mathrm{mol}
\end{aligned}
$$

The water influx into the combustion cavity promotes the steam-char reaction given under (4) and competes for process of heat for vaporization, which implies that there is an optimum ratio of water influx to air or oxygen injection rate which maximizes the product gas heating value.
Downstream from the reaction zone, the hot product gases heat the coal and cause pyrolysis and drying to occur. The coal is carbonized to form a char in the pyrolysis or devolatization zone which extends through the region having temperatures of $925^{\circ} \mathrm{C}$ to $350^{\circ} \mathrm{C}$. The hot product gases and steam can participate in additional reaction in this region as indicated below:

$\begin{array}{ll}\mathrm{CO}+\mathrm{H} 20--\mathrm{CO} 2+\mathrm{H} 2 & +41.0 \mathrm{~kJ} / \mathrm{mol} \text { (Water-gas } \\ \text { shift reaction) }(6) & \\ 2 \mathrm{CO}---\mathrm{CO} 2+\mathrm{C} & +172 \mathrm{~kJ} / \mathrm{mol} \text { (Boudouard } \\ \text { reaction) } & (7) \\ \mathrm{C}+2 \mathrm{H} 2 \text {---- } \mathrm{CH} 4 & +74.9 \mathrm{~kJ} / \mathrm{mol}\end{array}$

\section{UCG has become need of the hour:}

The world's energy needs are increasing and coal is still the main source of energy, its dependence is natural and is directly related to the economic growth of each country. Fortunately, India has all the potential and reserves for underground coal gasification. India has an estimated amount of around 467 billion tonnes (bt) [6] of potential reserves, nearly $66 \%$ of which is a potential candidate for UCG located in a deeper earth's crust that is difficult and uneconomical to mine with technical conventional, including that Coal at lower depths is likely to be of poor quality. The coal available in India is of poor quality and has a very high ash content with a low calorific value.

UGC has so many advantageous over the conventional methods of energy extraction from coal. Some of them are as stated below:

* Mining coal with conventional technique is eliminated with UCG, reducing operating costs, surface damage and eliminating mine safety issues such as mine collapse and asphyxiation;

* Coals that are not mineable economically (present at deeper depth, low grade, thin seams) can be exploitable by UCG, thereby greatly increasing domestic resource availability

* No surface gasification systems needed, as a result capital costs are substantially reduced

* Transportation of coal is not done at the surface, hence, reducing cost, emissions, and local footprint associated with coal shipping and stock piling

* Most of the ash present in the coal stays underground, thereby avoiding the need for excessive gas cleaning, and the environmental issues associated with fly ash storage and ground contamination is eliminated. 
There is no production of pollutants (e.g., SOx, NOx) and many other pollutants (mercury, particulates, sulphur species) are greatly reduced in volume and much easier to handle.

\section{METHODOLOGY}

UCG involves of injecting steam and air or oxygen into the coal seam from the surface well. The injected gases react with the coal present in the coal seam to form a combustible gas commonly known as syn gas, which is brought back to the surface in a production well, cleaned and this fuel or chemical feedstock to be used. By the process of combustion and as a result a cavity is formed due to the burning of coal and the roof collapses. This leads to lateral growth and can be continued until the product gas quality deteriorates. The greater the lateral growth, the longer the life of a gasifier and the more costeffective the operation.

The production of the product gas is due to the occurrence of various reactions between the gases and solid coal. The reaction that occurs between the solid coal and injected gases underground includes the following:

Major reactions are as follows:

Pyrolysis Coal + Heating (in absence of oxygen) $\rightarrow$ $\mathrm{Char}+\mathrm{CO} 2+\mathrm{CO}+\mathrm{H} 2 \mathrm{O}+\mathrm{H} 2+\mathrm{CH} 4$

Char Oxidation Char + Oxygen $\rightarrow \mathrm{CO} 2+\mathrm{H} 2 \mathrm{O}$

Steam Gasification Char $+\mathrm{H} 2 \mathrm{O} \rightarrow \mathrm{CO}+\mathrm{H} 2$

Water Gas Shift Reaction $\mathrm{CO}+\mathrm{H} 2 \mathrm{O} \rightarrow \mathrm{CO} 2+\mathrm{H} 2$

The main gases produced are $\mathrm{CO} 2, \mathrm{CH} 4, \mathrm{H} 2$ and carbon monoxide (CO). O2. $\mathrm{CH} 4$ is essentially a product of pyrolysis, rather than gasification. Its formation is favoured by low temperature and high pressure.

Underground coal gasification involves the same basic process / methodology as being used by other types of coal gasification, namely coal combustion, coal devolatilisation, steam gasification, carbon dioxide gasification and hydrogen gasification. A schematic diagram representing the processes is indicated in Figure 1 [7].

Figure : 1 shows a sequence from high temperatures from the oxidant injection point at the left to low temperatures at the production well, indicated at the right. Once the oxygen has been depleted by the combustion processes, the temperature of the gas starts decreasing due to the combination of endothermic gasification reactions, evaporation of moisture and heat loss from the surrounding coal and rock. The temperature developed by the gas has an impact on further reactions that can occur at significant rates, as gasification reactions normally takes place at a rapid speed at moderate to high temperatures. At lower temperatures devolatilisation will still occur, but at the production hole it is expected that only coal drying will take place.

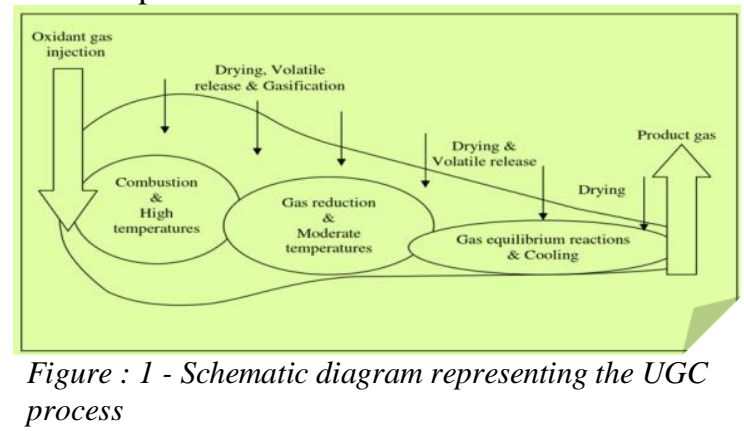

Water in the coal seam or the surrounding strata flows into the cavity and is required for the series of reactions that take place to produce raw syngas, a mixture of carbon dioxide (CO2), hydrogen $(\mathrm{H} 2)$, methane $(\mathrm{CH})$, carbon monoxide $(\mathrm{CO})$ and other contaminants like sulphur and trace metals. The gas mixture travels through the production well to the surface, where it is treated and cleaned as indicated in Figure 2.

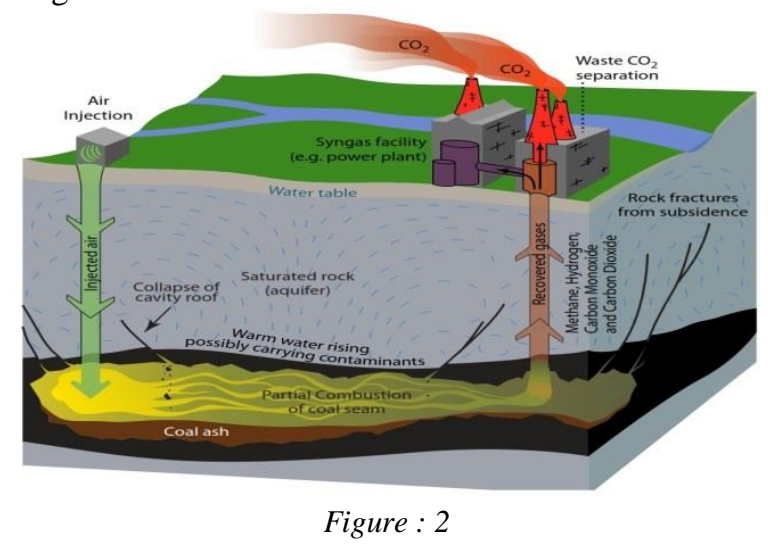

\section{Criteria for Site Selection Study:}

The characteristics that a desirable for a UCG site are as follows:

$\begin{array}{lll}\text { Coal seam } & = & 2 \text { to } 15 \mathrm{~m} \\ \text { Ash content } & < & 40 \% \text { (ad basis) } \\ \text { Seam dip } & < & 20^{\circ} \\ \text { Depth } & = & \begin{array}{l}300-400 \mathrm{~m} \text { with high } \\ \text { hydro static head } \\ \text { with low permeability }\end{array} \\ \begin{array}{l}\text { Over burden } \\ \text { good water }\end{array} & & \text { Nil } \\ \text { aquifers } & & \begin{array}{l}\text { Matching with the } \\ \text { economics of } \\ \text { Scale of deposit }\end{array} \\ & & \end{array}$




\section{Factors favourable for UCG Site Selection}

In-situ coal gasification is a high technology area. Some countries such as UK, USA and Australia have developed their own sets of criteria depending on local conditions. Following the important features concerning geology are taken into consideration during site selection for UCG:

Geography, topographical and technological features of the area.

Presence of faults, fractures, fissures etc and their orientation and extension.

Complete geology and geo data of coal seam as well as roof and floor which include complete lithology of overlying beds, coal bed and the floor rock.

a) Coal seam thickness

The thickness of the coal seam should be between 2 to $15 \mathrm{~m}$ with not more than $25 \%$ variation in the thickness throughout the coal seam. Variations in coal seam thickness can complicate drilling process of wells. Larger coal seam thickness have an advantage to greater use of the coal seam for gasification.

\section{b) Coal Depth and subsidence}

Researchers recommend more than $15 \mathrm{~m}$ of consolidated rock above the coal seam to prevent subsidence. Structural reliability of the underline rocks above the coal seam is required to support the overlying strata and the grounds surface. Additionally, relatively impermeable rock around the seam prevents the escape of product gases as well as reducing the flow of ground water into the seam.

c) Coal reserves and approachability

The reserves and availability of Indian coal have indicated that variety of bituminous, subbituminous and lignite coal are distributed all over India, located at different depths. Coal which when heated in the absence of air forms coherent beads, free from volatiles, with a strong and porous mass called coke, is called coking coal. Coals which do not have coking properties, are noncoking coals. Indian coal is mostly non-coking coal. A large quantity of such non-coking coal is available in India. India has a total of 253 billion tonnes of coal reserves[8]. The researchers found that under the site conditions, 33 million metric tons of coal converts to roughly 75.6 billion $\mathrm{m} 3$ of syngas.

\section{d) Coal composition}

The coal composition plays a very important role in site selection. The amount of Sulphur, moisture and ash present in the coal decides the quality of the syn gas. Coal with Ash above 50 percent decreases the heating value of the coal. Also if the moisture
Contents is below 15 percent the combustion process is favourable.

e) Coal porosity and permeability

The coal porosity and permeability within the coal seam can hinder or improve the flow of the syngas between the injection and production wells. Researchers recommend permeability values of 50 to $150 \mathrm{mD}$.

\section{f) Partings}

Partings are layers of clay, limestone, shale, sandstone, or other rock that locally separate the coal into multiple layers within a given seam. Partings can be problematic if they are located near ignition points, injection wells and production wells. Researchers recommend a single layer parting that should be less than one meter in thickness. With a parting more than one meter thick, the syngas heating value will drop and gasification may prove impossible.

g) Depth and aquifers

It has been observed that optimal coal seam depths exist between 92 to $460 \mathrm{~m}$, with the preference for seams below $200 \mathrm{~m}$ to avoid subsidence issues. Deeper gasification projects are also desirable due to their increased separation from potable groundwater aquifers. Thus, deeper the coal seam, the less risk of contaminating underground sources of drinking water (USDW).

h) Coal seam angle (dip)

The desirable dip of the coal seam should lie between 0 and 70 degrees with less than 2 degrees in angle variation in order to avoid problems with drilling. As the angle in the seam increases, the potential for damaged equipment and material in the seam rises accordingly. Still, a coal seam with a slight angle is favourable for UCG because it helps to move water and ash away from the area where oxidation occurs.

\section{CONCLUSION}

Our analysis of the current status of UCG shows that this technology has a great potential to grow and replace/complement traditional methods for coal mining and surface gasification. New commercial UCG projects have started recently in several countries, and more projects will probably start soon. Selection of the best UCG technology is a complex process, and a variety of technical and geological factors must be taken into consideration for each site being evaluated.

\section{REFERENCE}


[1] Abha Rani, Udayan Singh, Jayant, Ajay K Singh, Siba Sankar Mahapatra, "Performance, cost and environmental assessment of gasification-based electricity in India", $A$ preliminary analysis", IOP Conf. Series: Earth and Environmental Science, 76, 2017.

[2] Anil Khadse, Mohammed Qayyumi, Sanjay Mahajani, Preeti Aghalayam, "Underground coal gasification", A new clean coal utilization technique for India: Elsevier's - Science direct, Energy 32 (2007) 2061-2071.

[3] Badri Narayanan, Somya Mathur, "The potential impact of $\mathrm{GHG}$ reductions on air pollution in India" ,Journal of the Asia Pacific Economy, pp 344-360, 2021.

[4] P.K.Jain, "Underground Coal Gasification

- Experience of ONGC", IOP Conf. Series: Earth and Environmental Science 76 (2017) 012004.

[5] Mojibul Sajjad, Mohammad G. Rasul, "Prospect of Underground Coal Gasification in Bangladesh", Procedia Engineering, pp 537 548, 2015.

[6] Elizabeth Burton, Julio Friedmann, Ravi Upadhye, "Best Practices in Underground Coal Gasification Lawrence Livermore National Laboratory" 2019.

[7] Andrew Beath, Stuart Craig, Anna Littleboy, Rusty Mark and Cliff Mallett, “ Underground Coal Gasification: Evaluating Environmental Barriers: Exploration And Mining”, Exploration And Mining Report P2004/5, 2004.

[8] Vyas, D. U., R.P.Singh, "Worldwide developments in UCG, and Indian initiative", Procedia Earth and Planetary Science, Volume 11, pp 29-37, 2015. 